This item was submitted to Loughborough's Research Repository by the author.

Items in Figshare are protected by copyright, with all rights reserved, unless otherwise indicated.

\title{
College basketball governance in the Philippines: actors, stakeholders, issues, and challenges
}

PLEASE CITE THE PUBLISHED VERSION

https://doi.org/10.1080/17430437.2018.1490265

\section{PUBLISHER}

(C) Taylor \& Francis

\section{VERSION}

AM (Accepted Manuscript)

\section{PUBLISHER STATEMENT}

This is an Accepted Manuscript of an article published by Taylor \& Francis in Sport in Society on 27 October 2018, available online: http://www.tandfonline.com/10.1080/17430437.2018.1490265.

\section{LICENCE}

CC BY-NC-ND 4.0

\section{REPOSITORY RECORD}

Blanco, Dennis V., and Alan Bairner. 2018. "College Basketball Governance in the Philippines: Actors, Stakeholders, Issues, and Challenges”. figshare. https://hdl.handle.net/2134/35745. 


\title{
College Basketball Governance in the Philippines: Actors, Stakeholders, Issues and
}

\section{Challenges}

\begin{abstract}
Collegiate basketball is one of the most popular and most watched forms of amateur sport in the Philippines. Like any sport, collegiate basketball is governed by actors and stakeholders and characterized by issues and challenges. Employing a policy-capacity and synthesis integrative review approach, this article identifies the actors, stakeholders and institutions of the Philippines two leading college basketball leagues, namely, the Universities Athletic Association of the Philippines (UAAP) and the National Collegiate Athletic Association (NCAA) and analyses the critical issues that confront these leagues in the context of college basketball governance. Issues include an overly powerful board of directors in relation to league commissioners, a lack of accountability mechanisms, alleged piracy of coaches and players, recruitment of players and coaches, the two-year residency rule, and parity in media coverage. Accordingly, the article assesses necessary on-going policy capacities and reforms which college basketball leagues undertake to achieve sound governance.
\end{abstract}

Keywords: basketball, governance, policy, sports, synthesis

\section{Introduction}

Basketball is a sport about which Filipinos are passionate. It is no surprise, therefore, that the Philippines is dubbed a basketball-crazy republic because of the amount of enthusiasm that fans put into every game that they watch. Compared with basketball, baseball and football are mere afterthoughts (Bartholomew 2011). 
College basketball in the Philippines is an interesting phenomenon which draws a huge following and attracts spectators from all walks of life, thereby making basketball in the Philippines very much alive, sustainable and dynamic, whether the sport is played in Metro Manila in the Universities Athletic Association of the Philippines (UAAP), the National Collegiate Athletic Association (NCAA), the National Athletics Associations of Schools, Colleges and Universities (NAASCU), the National Collegiate Regional Athletics Association (NCRAA), or in Metro Cebu in the Cebu Athletics Association of Colleges and Universities in the Philippines (CAACUP), or at the national level in the Philippine Collegiate Championship League (PCCL) and the Flying V College Basketball Invitational. College basketball leagues demonstrate that the popularity of basketball in the Philippines is anchored in its "continued practice and following of the sport by ordinary individuals that sustains its prominence in the country" (Antolihao 2015, 182). However, the governance of these college basketball leagues is not without issues and challenges that need to be resolved and overcome through policysolutions and policy-capacities for the achievement of good governance goals and objectives.

With this in mind, the aim of this article is three-fold. First, it focuses on the two premier and leading collegiate basketball leagues in the Philippines, namely, the Universities of Athletic Association in the Philippines (UAAP) and the National Collegiate Athletic Association (NCAA) identifying their membership, governance structures and processes. These leagues have been chosen because of their longevity, popularity, stability, and alumni and fan support. Second, the article analyses the emerging issues and challenges involving college basketball governance, specifically in the context of a developing country such as the Philippines, as evidenced and contextualized in the UAAP and NCAA collegiate basketball leagues. Finally, the article 
highlights on-going policy-capacities which may be present or lacking in devising solutions and remedies to the issues and challenges affecting college basketball governance in the Philippines.

We article argue that potential and on-going policy-reforms are needed to strengthen and the college basketball league's institutional capacities in the areas of governance. This includes the attainment of mission and vision, effective formulation and implementation of rules and regulation, the exercise of real powers on the part of boards of trustee and the orchestration of future strategic directions and goals. Hoye and Cuskelly (2007) posit that the concept of governance in the context of sport centres on three areas: structures and processes, goals and directions, performance monitoring and board control, while O' Boyle and Bradbury (2013) state that governance involves four dimensions, namely, the provision of a clear direction that aligns with the mission and vision of the organization, the delegation of power, the issue of regulation and the concept of control.

For the purposes of this article, college basketball governance is defined as "an act of governing college basketball organizations which involves and engages all actors and stakeholders such as the government, basketball leaders, boards of directors, school owners, team managers, coaches, players, alumni, media and private corporations in a deliberative, participatory and consensual manner to be able to achieve the basketball organization's mission and vision, implement effective rules and regulations, assert board control and authority and orchestrate future strategic direction and goals through various political, managerial, analytical and technical capacities". 


\section{Method}

The study is based on a qualitative approach employing (1) policy-capacity analysis to evaluate Philippine college basketball in the context of governance structures, processes and arrangements and the impact of policy-capacities and policy-changes on college basketball organizations and (2) an integrative review approach which provide knowledge synthesis and understanding in order to develop future policy capacity remedies and solutions in the governance of college basketball organizations in the Philippines.

The method employs a policy-capacity analysis of college basketball governance using available literature and considering implications for the Philippines. Policy capacity is concerned with the acquisition and utilization of policy relevant knowledge that contributes to the establishment of medium and long-term planning, framing options, the application of both qualitative and quantitative research methods, communications, and stakeholder management strategies (Olipant and Howlett 2010).

An integrative review was also utilised based on the methodological proposals of Whittemore and Knafl (2005). An integrative literature review seeks to provide a comprehensive understanding of a topic and produce new knowledge through the synthesis of existing information. The criteria used for the literature search include policy-based approaches, theorientation, significance and relevance of their perspectives and findings supportive of the paper's thrust and objectives.

Literature on basketball was sourced via the electronic database EBSCO s and personal searches of journals, sports websites, and books published in the period from January 1983 to May 2016. The overall search was limited to work on basketball published in English using key 
words such as "basketball", "basketball governance", "college basketball” and "basketball policy" as the basis for literature search.

Articles retrieved included a range of methodological approaches, including both experimental and non-experimental studies. The review focused primarily on articles using a policy-based approach, and then employed critical analysis through the assignment of meanings and interpretations to the perspectives, issues, challenges and opportunities presented in such articles.

\section{Analysis and Discussion}

This section presents the premier and leading college basketball stakeholders in the Philippines, namely the Universities Athletic Association of the Philippines (UAAP) and the National Collegiate Association of the Philippines (NCAA), in terms of membership, mission and vision, and governance structures. The college basketball governance actors and stakeholders are interrelated, coordinated and collaborative in terms of collective goals and pursuits in the development of Philippine competitive basketball at the local, regional and international levels.

College Basketball Governance in the Philippines: Actors, Structures, Powers and Regulations

\section{The Universities Athletic Association of the Philippines (UAAP)}

The Universities Athletic Association of the Philippines is one of the premier college basketball leagues in the country. It has eight member school teams, namely Adamson University Soaring 
Falcons, Ateneo de Manila University Blue Eagles, De LaSalle University Green Archers, Far Eastern University Tamaraws, National University Bulldogs, the University of the East Red Warriors, the University of the Philippines Fighting Maroons, and the University of Santo Tomas Growling Tigers. The UAAP's paramount mission is to promote ideal sportsmanship on the basis of camaraderie, fraternity, unity, excellence, goodwill and amity among its member schools.

The governance structure of the UAAP consists of a UAAP League Commissioner elected and appointed by the UAAP Board members on an annual basis. The UAAP Commissioner is in charge of the implementation of the rules and regulations, officiating, technicalities and other game-related concerns.

UAAP Board of Directors, known collectively as the UAAP Policy Board, are charged with two general duties. The first is to act as a policy-making body which decides the general rules and regulations or policy directions of the UAAP in terms of Mission-Vision. The second duty is to operationalize these policies. The one-year residency for transferring athletes and the policy on foreign players are but two of the responsibilities that have to be tackled. In addition to policy-making, the UAAP board is interested in the progress of the league for its spectators and may be appointed from time to time to ad hoc committees (Lichauco and Jacinto, 2014).

The board meets every month and each meeting can last for up to six hours. Being a part of the Eligibility Committee means meeting at least two weeks prior to an event to screen the line-up of each participating university. Moreover, other meetings, including research for ad hoc committees, emergency meetings, meetings for the staff and coaches, and preparations for the events are just a few of the things required of a UAAP board member. In addition, as members of the board, they must be present at games as often as possible (Lichauco and Jacinto 2014). 
Some of the issues which the UAAP encounters include the two-year residency rule for high school students coming from one UAAP school and transferring to another UAAP member school, the one-year residency rule for foreign imports, the maximum allowance payable to top recruits, and the piracy of players and coaches.

\section{The National Collegiate Athletic Association (NCAA)}

The NCAA is the oldest college basketball league in the Philippines and remains one of the premier college basketball leagues in the Philippines. It was founded in 1924 and its initial members were the University of the Philippines (UP), Ateneo de Manila University (ADMU), De La Salle College (DLSC), the Institute of Accounts (now Far Eastern University), the National University (NU), San Beda College (SBC), the University of Manila (UM) and the the University of Santo Tomas (UST).

It is worthy of note that the all the original members, except for San Beda College, have already transferred to its current rival league - the UAAP - while the University of Manila has withdrawn completely. As a result, today the NCAA has ten member schools, namely Colegio de San Juan de Letran Knights, San Beda Red Lions, San Sebastian Stags, Mapua Cardinals, the University of Perpetual Help Altas, Jose Rizal University Heavy Bombers, the Lyceum of the Philippines Pirates, Arellano University Chiefs, the College of Saint Benilde Blazers and Emilio Aguinaldo College Generals.

Its objectives include promoting good relationships among institutions of learning that offer courses approved by the Department of Education at the secondary level and the Commission on Higher Education at the tertiary level; establishing and maintaining uniform rules for the government of college and high school sports; instituting, regulating, and awarding 
college and high school athletic championships; promoting competitive sports founded on physical, moral, and spiritual values; and cooperating with the national sports associations in all matters pertaining to amateur sports activity as an established student-athlete nursery.

Its governance structure is composed of an NCAA League Commissioner whose functions and responsibilities are to implement and enforce the league's rules and regulations, ensure that there is fair, honest and just officiating of games and resolve disputes and protests arising from game-related technical matters.

The Policy Board, composed of the President's member schools manages the NCAA's external and internal affairs. It handles matters such as acceptance, replacement, and suspension of member schools. The NCAA presidency rotates among member schools. The other main administrative body of the NCAA is the Management Committee (MANCOM) which determines matters of athletic concern, such as determining the proper condition for playing, suspension of players, coaches and referees, reversals or reviews of game results, and investigation of ineligible players. The management committee consists of the athletic moderators or athletic directors of member schools who are selected by their respective university presidents, and the league chairperson, who is selected by the policy board. Like the league president, the chair of Management Committee rotates among member schools (chanrobles.com).

The president of the Policy Board and Chairperson of the Management Committee come from the school currently hosting the basketball tournament. The rotation is determined by the order in which each school joined the league. The host school manages the logistics, expenses, labour and security at the venue. Each sport has its own host, with the host for the basketball being the head of the hosts (wikipilipinas.org) 
Since the earliest known constitution on record - the 1947 NCAA Constitution - was formulated by the NCAA Athletic Board of Controls, the body of rules governing the association has undergone several reviews and revisions to cope with the dynamic development of sport. The NCAA Policy Board and Management Committee has recently enacted the 2014 NCAA Constitution and By-Laws, the result of a concerted effort on the part of the Policy Board and the Management Committee with the objective of improving the provisions of its predecessor for more comprehensive implementation of policies and procedures.

\section{Collegiate Basketball Governance in the Philippines: Issues and Challenges.}

College basketball in the Philippines involves issues which may be common to all basketball leagues and organizations. For example, all college basketball leagues in the Philippines consist of similar actors and stakeholders - coaches, players, school owners, league presidents, commissioners and boards of directors, students and alumni, fans and spectators. The issues referred to in this section cut across college basketball leagues in the Philippines in one way or another and such issues affect college basketball organizations in terms of achieving their mission and vision, implementing their rules and regulations, exercising board control and direction and charting future directions. Groeneveld and Houlihan $(2012,10)$ state that:

Governance is centrally concerned with power - its distribution, the way in which it is exercised, and the arrangements for controlling the powerful. The current academic literature on governance tends to focus on three overlapping themes the first two of which- governance as networks and governance as steering, are primarily concerned to explain the changes in the relations between organizations, especially between 
government and organizations of civil society. The third theme-good governance- is more concerned with internal management of organizations.

Issues discussed here are a) having an overly powerful board of directors in relation to league commissioners and member school presidents and rectors, b) a lack of accountability mechanisms and reporting requirements for boards of directors, c) player and coach piracy, d) the reinforcement of foreign import players, e) the two year residency rule, f) parity in media coverage, and g) commercialization of college basketball teams. These are issues which precipitate policy-changes and organizational restructuring in both internal and external structures, processes and relationships that govern college basketball organizations.

More importantly, these are issues and challenges that merit discussion and deserve closer examination for the following reasons: Firstly, these are the very issues which involve and affect college basketball actors and stakeholders from the top - commissioners, presidents and boards of directors - down to the lowest echelons - the coaches, players and fans, together with other external stakeholders such as the media and commercial entities. Secondly, these are issues and challenges that characterise and depict the on-going and existing policy gaps which demand sound policy-reforms, innovations and initiatives in terms of governance for the betterment of the college basketball leagues. Finally, these issues and challenges were chosen on the basis of their relevance and functionality to the potential and actual policy-capacities which the college basketball leagues formulate, implement and undertake to improve in terms of efficiency, effectiveness and ethical governance. 


\section{Having an overly powerful Board of Directors in relation to the League Commissioner}

The organizational structures of the UAAP and NCAA grant more powers and opportunities for boards of directors to overturn, circumvent and veto some of the decisions and judgments made by the commissioner relating to appeals and complaints concerning game results over which the board has jurisdiction. The Board has full discretion to make decisions even on game-related issues despite the fact that the commissioner has already made a decision on the matter in question. Consider these events as described by Terrado (spin.ph, 2014):

Just last season, basketball commissioner Chito Loyzaga handed a two-game suspension

to University of the East center Charles Mammie for a third unsportsmanlike foul, only for the board to reduce the suspension to one game following an appeal made by the Red Warriors. During the term of former commissioner Ato Badolato two seasons ago, the board also overturned a decision on the court and ordered a replay of a match between National University and Far Eastern University.

The above-mentioned cases demonstrate how much power a board of directors can exert over league commissioners in deciding the outcome of protests, complaints and petitions arising from technicalities, proficiencies and results of games. Although it can be said that the board has the right to try to decide on these appeals and cases, and this is consistent with the principles of checks and balances aimed at limiting the powers of the commissioner, such a power structure renders the commissioner irrelevant, possessing only symbolic power in relation to the interpretation and implementation of league rules and in the promulgation of game time decisions as he or she deems fit in accordance with the league's by-laws and constitution. Ultimately, final decisions rest with the board of directors who are accorded the power to veto, overturn and circumvent the league commissioner's decision. 
It is probably the policy and practice of placing the appointment of the league commissioner solely in the hands of the host school that justifies and rationalizes the checks and balances mechanism accorded to the Board of Directors to review, amend and revise previous judgments and decisions made by the league commissioner concerning technical matters, the interpretation of the rules, game results and game time decisions. Allegations and suspicions of biases and partiality related to a commissioner appointed by the host member school suggest a tilting of the balance in favour of the host school in terms of officiating and decision-making. However, broadening the involvement and participation of all the member schools in the choice and selection of the league commissioner would mean a necessary and sound reform that would make such appointments democratic, accountable, transparent and credible.

\section{Lack of accountability of the Board of Directors to the Presidents or Rectors of the member schools}

The governance structure of both the UAAP and NCAA allow the Board of Directors or the Policy Board of the UAAP and the Management Committee (MANCOM) respectively enormous power and authority with regards to the planning, formulation and implementation of the league's policies, programmes and projects. They are in charge of matters of athletic concern, such as determining the proper conditions for playing, the suspension of players, coaches and referees, reversals or reviews of game results, and the investigation of ineligible players. They are also the policy-making bodies tasked with drafting and formulating the general rules and regulations or policy directions of the league in terms of Mission-Vision, with ensuring the Mission is translated into the general rules and consequently with implementing and actualizing these rules and regulations and policy-directions. 
The UAAP and NCAA differ in terms of governance structure and composition. The UAAP Board of Directors or Policy Board consists of an athletic director or Physical Education Director as the first board member and a professor or a member of the administration as the second board representative. The NCAA Board of Directors is composed of member school presidents (for non-sectarian school) and rectors (for sectarian schools).

It should be noted that prior to UAAP Season 80, the UAAP governance structure precluded presidents and rectors from active participation in the league's policy-making, implementation and decision-making body and relegated their duties to merely ceremonial and symbolic functions such as attendance at opening ceremonies, tossing the ball during the opening jump ball, attending meetings, signing and approving letters, documents and papers on behalf of the university or college. The real power and important functions were given to their respective boards of representatives in terms of policy-making, planning, formulation, implementation and decision-making in matters concerning the league. But after eighty years, the league now designates the heads, presidents and rectors of member schools to become automatically members of the Board of Trustees with corresponding authentic and direct powers in the formulation, planning and implementation of the leagues rules as well as being given 'hands on powers' to char the future direction of the league starting with UAAP Season 80.

The NCAA, on the other hand, allows the presidents and rectors of its member schools to perform an increasing leadership role in the league's governance as is evident in its Policy Board or Board of Directors whose membership consists of the member schools' presidents and rectors and in which actual and real power resides in terms of managing the internal and external affairs of the league. An accountability mechanism is in place through which the Policy Board monitors and supervises the Management Committee (MANCOM), whose representatives are athletic 
directors, professors or members of administration directly reporting and accountable to their respective presidents and rectors. This is a counterpart of the UAAP Policy Board. Henson, (2013) notes, however, the glaring difference in governance accountability structure between the two collegiate basketball leagues when he comments that:

In the NCAA, a Policy Board composed of school presidents looks over the shoulders of the Management Committee. In the UAAP, there is no counterpart of a Policy Board. That's why the UAAP Board has full discretion to make decisions even on gamerelated issues whether the Commissioner likes it or not. This season, the Board went overboard in reinstating a suspended player only hours before a game, implementing eligibility rules with immediate effectivity (when the usual practice is to implement after a year) and sanctioning individuals without due process. Backroom alliances to protect parochial interests make for a highly politicized Board where the rightfulness of a particular issue may no longer be the critical factor of decision-making.

However, even though the NCAA possesses an accountability mechanism structure that allows the presidents and rectors (Policy Board) to monitor, supervise and evaluate the performance of its management committee members, the adoption of a more stringent mechanism which would put an emphasis on honest and accountable reporting requirements such as the creation of risk and audit committees which its UAAP counterpart is currently doing, could be an example of best governance practice which it could be emulated to prevent occurrences of violation and deviation and ensure adherence to the accountability rules and mechanisms by its MANCOM representatives. It seems that both each basketball league can learn from the other through sharing and imitating one another's governance best practices and incorporating or operationalizing these in its general guidelines, as well as in its rules and 
regulations, for the betterment of their respective league's governance and management structures.

\section{Alleged piracy of players and coaches}

Universities and colleges scout and recruit leading players, especially high school basketball stars, from other schools either in the provinces and cities. Top universities in the UAAP and NCAA can afford to recruit the best talent available among high school basketball players by virtue of the promise of quality education and the established prestige and reputation enjoyed by players or coaches who have been hired by such elite universities.

For example playing or coaching in men's basketball team such as De La Salle University and Ateneo De Manila University in the UAAP, San Beda College and Colegio de San Juan de Letran in the NCAA is every player or coach's dream and boosts one's honour and prestige not only because these are considered the top tier universities and colleges in the Philippines but also because their famous rivalries and the strong financial backing they enjoy from their renowned alumni, sports patrons and other generous benefactors which makes it possible to provide large allowances, convenient accommodation, and a strong fan base.

All of this is evidenced by occurrences of top high school players, most of them coming from a champion team and adjudged to be a Most Valuable Players (MVP), such as Jerie Pingoy of Far Eastern University Baby Tamaraws (FEU) and Herbert Cani of National University Bullpups, transferring to their school rival, Ateneo De Manila University. Both players however were consequently removed from the university roster due to their academic deficiencies and were later transferred to Adamson University and Far Eastern University respectively. 
This is also supported by the fact that the recruitment and transfer of star players already playing in rival leagues such as CESAFI, a collegiate basketball league based in the Visayas. These include seven-footer Gregory Slaughter who moved from University Visayas Lancers to Ateneo De Manila University, and more recently, Cameroonian Ben Mbala who transferred from University of Visayas Green Lancers to De La Salle University and NCAA's C. J. Perez of San Sebastian Stags who transferred to Ateneo De Manila University Blue Eagles but finally settled at the Lyceum University of the Philippines which he steered its first-ever runners-up position, losing to the multi-titled San Beda College Red Lions Season 93 NCAA Men's Basketball finals.

These transfers of high calibre players from one school to another and from one league to another have compelled the management committee and policy board members to formulate and implement a two-year residency rule for top recruits from high schools in the same league and star players from the other leagues need to sit out and complete a two-year residency rule before they can play. This is done to prevent player piracy and uphold the spirit of amateurism according to which the player is a student first and an athlete second. This provision promotes a sense of fairness and justice towards the school which was responsible for training, harnessing and honing the talent of the player and thereby essentially planted the seeds of potential greatness once harvested by other rival schools and league competitors.

The resignation of champion coach Aldin Ayo who guided Colegio De San Juan De Letran Knights to its 2015 NCAA Men's Basketball Championship by upsetting the five-time NCAA Champions San Beda Red Lions and his move to De La Salle University Green Archers which had performed poorly that year in the UAAP became controversial because Ayo is an Letran alumnus. Moving from his alma mater and accepting the coaching position offer made by La Salle - its then rival in the NCAA - was a bitter pill to swallow for Letran players, school 
officials, students and alumni. Ayo was allegedly offered a lucrative deal equivalent three times his previous salary at his alma mater, Colegio De San Juan De Letran, which he could not resist But Ayo denied this accusation and claimed that his transfer was not about money or politics but personal family and business problems.

\section{Commercialization and corporatization of college basketball}

Collegiate basketball teams in the Philippines are increasingly becoming quasi-commercial with major private corporations bankrolling and subsidizing the salaries and allowances of coaches, players, trainers and other staff members. The corporate backers exert tremendous influence over the selection of coaches and players and charting the college basketball programme. As previously discussed, business magnates turned basketball sport godfathers such as Eduardo Cojuangco Jr. of San Miguel Corporation and Manuel V. Pangilinan of Metro Pacific Group of Companies play an instrumental role in the development of the basketball programmes of their former universities - De La Salle University and Ateneo De Manila University - respectively.

Juico (2014) narrates the state of Philippine college basketball in retrospect when he comments, "One recalls that during those times, only the playing jersey and the pants were given to the players. They had to pay and/or beg for the coveted team jacket and pay for their own shoes. Medical treatment was to their account, in case of injuries. They were not allowed to play for certain grading periods, if, during that particular period, they had one or two failing grades in any subject. Times have, however, changed and the Philippines, which adopted the American educational system, including physical education and collegiate sports, which has followed the American style of "incorporating elite athletics into its educational system." 
But it is not only the San Miguel Corporation and Metro Pacific Group of Companies that are openly supporting the basketball programmes of college teams in the Philippines. Mall giant, Shoe Mart (SM) and Banco De Oro, owned by one of Asia's richest billionaires, Henry Sy, have recently joined the fray. In fact, Sy has already taken over the ownership of National University through his son, Hans Sy, a such change of ownership which is largely instrumental and is linked to the National University Bulldogs victory in the $78^{\text {th }}$ Season of the UAAP Basketball Championship when they defeated the favoured Far Eastern University Tamaraws and ended the school's title drought lasting sixty years in the process.

Other companies which are supporting or having links with college basketball programmes include Akari (Adamson University Soaring Falcons), Dickies (University of Santo Tomas Growling Tigers), and Café France (Centro Escolar University Scorpions). Even boxing champion Manny "Pacman" Pacquiao has joined the bandwagon by sponsoring a college basketball programme when he took his seat as the team manager of Colegio de San Juan De Letran Knights which turned out be a blessing in disguise as the team beat the San Beda College Red Lions to win the much-coveted 2015 NCAA Men's Basketball Championship.

The commercialization of college basketball has its advantages and disadvantages. It means solid and robust financial support for school's basketball programmes which enhances team morale by removing concerns about allowances, uniforms and sneakers, water, food, vitamin supplements, diet and nutrition, board and lodging expenses and other financial considerations. This enables the team to concentrate on its training and playing without material, financial, technical and logistical constraints. It also frees the colleges and universities from shouldering the financial costs of maintaining and managing a basketball team alone and enables 
them to free up certain operational expenses which would otherwise be have been allotted for contingency funds for its athletic programmes.

On the other hand, the commercialization of college basketball in the Philippines stifles the very concept and spirit of amateurism when colleges with rich corporate support are able to lure the most talented players with offers of perks which other colleges and universities may find it impossible to match. This affects the parity of the league in terms of balanced line-ups and the competitiveness of teams which do not have the luxury of robust and comprehensive corporate sponsorship and company support.

The commercialization of college basketball leagues also diminishes the capacity of school athletic officials to plot the direction of basketball programmes and directly, or by implication, transfers the power over the recruitment and selection of players and coaches to the sponsoring companies or corporations. There is then the possibility of coaches and players' loyalty to the backers taking precedence over school loyalty, especially in the case of coaches and their staff since it is the company boss who pays their salaries. Furthermore, the commercialization of the collegiate league veers away from the very foundations on which college basketball was built, namely to foster goodwill and sportsmanship the basis of promoting school and loyalty.

\section{The recruitment of foreign players and coaches}

The hiring and recruitment of imported foreign players is an emerging issue in Philippine college basketball. Overseas imports have become a regular feature of college basketball. There are very few teams without foreign players, mostly African and American imports. Currently in 
the UAAP and NCAA, teams are allowed two foreign students (i.e. without Philippine blood) per roster, but with the decree that they cannot play on the court at the same time as each other.

Most of them are African - from Nigeria, Cameroon, Sierra Leone, the Congo (the former Zaire) and Ghana - for the simple reason that they are as athletic as African-Americans but are cheaper to recruit by way of payoffs to sports agents and in terms of monthly allowances to the players. However, the foreign recruits are still paid well. They receive free tuition, rented condo units, high-end vehicles, additional tutoring for the academically-challenged and, of course, a monthly allowance. All these benefits are courtesy of the rich businessmen among the alumni communities (Liao 2014).

In the UAAP, for example, foreign imports include Emmanuel Mbe and Alfred Aroga (NU), Moustaph Arafat and Charles Mammie (UE), Karim Abdul (UST), Ben Mbala (DLSU), Ingrid Sewa and Papi Sarr (ADU), Christian Sentcheu (FEU) while in NCAA the likes of Sam Ekwe, Ola Oldegun and Pierre Tankoua (SBC), Dionce Holts (Arellano University), don school basketball uniforms, demonstrating the extent to which college basketball in the Philippine relies on foreign imports to strengthen their line-ups and increase chances of success. However, there are competing arguments for and against this practice which will be discussed in the next section which deals with policy-capacity analysis in college basketball.

However, it is not only the recruitment of foreign players that emerges as a critical issue in college basketball in the Philippines. Foreign coaches are also approached to mentor young collegiate players in the league. Ateneo De Manila Blue Eagles's hiring of coach Tab Baldwin, a New Zealander, also the coach of the men's basketball team, Smart Gilas, and a former national coach of New Zealand men's basketball team, as its new varsity coach became controversial for the Basketball Coaches Association of the Philippines (BCAP) which threatened to block such 
appointments because they deprive local coaches of the opportunity to coach a local collegiate team. BCAP stressed that Filipino coaches are as competent and skillful as other coaches around the world. But in the end, the Association withdrew its intention to block such appointments following its dialogue with coach Baldwin and Samahang Basketbol ng Pilipinas thus opening the way for the first-ever foreigner to coach a local collegiate basketball squad with the exception of Norman Black, an American who later acquired his Filipino citizenship.

\section{The Two-Year Residency Rule}

The two-year residency rule is challenged by some college basketball teams because it dictates that a newly-recruited high school student player from another school must sit out for two years before he or she can play in the league. The rationale behind the policy is to prevent player piracy and to make the newly-recruited players focus first on their studies

This rule became prominent when Jerie Pingoy, the MVP of the UAAP Juniors Basketball from FEU, decided to move to its rival team, Ateneo De Manila Universit,y which prompted the UAAP Board to formulate and implement the two-year residency rule. The twoyear residency rule became popularly known then as the 'Pingoy Rule'. The argument in favour

of such a rule puts a premium on an honest and fair assessment on the part of the high school player's original school which has prepared, trained and honed the talent of the player, taking into account that the player could potentially later move to the senior basketball team and become the focal point of a rebuilding process only to be recruited by other school.

However, those who are against such a policy consider it to be a violation of student athletes' rights, arguing that the high school student athlete has the right to choose in which 
colleges and universities they want to enroll as part of the Magna Carta for Students on academic freedom. Furthermore, the rule restricts and represses the student athlete's capacity to demonstrate their basketball talents and skills immediately in order to maximize their promise and potential as student athletes. The policy is also said to affect the students' morale and selfesteem knowing that they used to be best players at high school but are no to be relegated to the role of mere spectators, watching from the sidelines when their teammates play. This is even more painful when the team loses because a defeat gives the student athletes a guilty feeling that they could be out there playing and contributing on the court. These arguments caught the attention of Senator Pia Cayetano who began lobbying for the Republic Act 10676 (the Student Athletes Protection Act) which will be discussed in a separate section of the paper amongst policy-capacity solutions.

\section{Parity in media coverage}

As previously discussed, the UAAP and the NCAA consist of member schools located in Metropolitan Manila which are more popular and famous compared with the member schools of other collegiate leagues. This is attributable to the media coverage that that these leagues enjoy thereby making their appeal wider in terms of audience market. ABS-CBN Sports ActionChannel 2 on the regular band owns the right to broadcast the live game of both the UAAP and the NCAA, with UAAP games nationally televised during weekends and NCAA games are aired live nationally every Monday, Wednesday and Friday.

ABS-CBN station's strong and far-reaching signals enable basketball fans all over the archipelago to watch the fancied and storied rivalry between De La Salle University Green Archers and Ateneo De Manila University Blue Eagles in the UAAP and the historic rivalry 
between San Beda College Red Lions and Colegio de San Juan de Letran Knights on television sets in Luzon, Visayas and Mindanao. These college basketball teams are household names, thanks to this national media coverage which helps them to acquire a broader fan base. UAAP and NCAA basketball games attract a large share of the audience market compared with other leagues which makes television executives show interest in them as sources of income revenues. This in turn is good for the leagues as it strengthens their financial viability and that of their member schools though commercials and advertisements not to mention the money earned from gate attendance receipts.

It can also be argued that basketball has kept the other collegiate sports from disappearing. Without the millions in revenue that basketball brings into the UAAP and the NCAA, schools would be hard-pressed to fund other sports. In the UAAP, tennis took in a grand total of P23, 000 in gate receipts and sales this year, a distant second to the top-earning basketball's P18.7 million. This is not counting the income generated by basketball from its TV deal. For this year, enough income was generated by basketball to allow the UAAP to give back a total of P1.8 million to its eight member-schools, P220, 000 each, for general sports development (Dy 2005).

This is not the case with other basketball leagues, some of which are televised on a regional and community channels only. Others are broadcasted on a delayed basis or are not televised at all. It is one of the primary objectives of the National Collegiate Championship (NCC), formerly known as the Philippine Collegiate Championship League (PCCL), to provide exposure to other collegiate basketball teams in the country through national broadcasting of games to give equal opportunities to basketball players, especially from the lesser known leagues and the provinces, to show that they too are competitive and talented. This competition brings 
together the champion teams from different leagues to compete for the real national championship. Its tournament format, however, is criticized for being lopsided in favour of UAAP and NCAA teams and is thought to require re-evaluation on the basis of fair, equitable and just competition.

\section{College basketball governance policy-capacities in the Philippines: a critical analysis}

There are laws and policies that address the issues and challenges facing collegiate basketball in the Philippines involving policy-capacity solutions and remedies which are intended to ensure the preservation of collegiate basketball players' spirit of amateurism and to protect the rights and welfare of the players and the league in general while fostering unity, excellence and goodwill through basketball. Adherents to this traditional perspective argue that "sports law simply entails the application of basic legal precepts to a specific industry that is drawn from other substantive areas of the law" (Mitten and Davis 2012, 1). The following section analyses the policy-capacities and policy-reforms which college basketball leagues formulate and implement to resolve the critical issues and challenges besetting college basketball governance in the Philippines.

\section{Deliberative appointment and empowerment of a long-term league commissioner}

The regular practice of college basketball leagues is to appoint a league commissioner on a one-year basis to be replaced by a new commissioner for the next season. This, however, leads to instability and inconsistency in the league because the yearly replacement of the league commissioner also means different sets of referees and technical committees and different modes 
of interpretation. What is even worse is that this practice encourages the changing of the tournament directorship each year. Different managers have different management styles. Different referees have different training, and even differing interpretations of the rules. Thus, if host schools keep changing commissioners and referees, teams have to adjust to their styles annually (Roque, 2016).

A long-term commissioner is good for a league for this can provide stability and consistency. A long-term appointee would be able to gain mastery of the rules, regulations and technical matters concerning the league and also formulate and implement of long-term plans, programmes and projects for the betterment of the league that are more achievable because the continuity and sustainability of such strategies and programmes can monitored, checked and evaluated. A seasonal appointed commissioner's hands are tied, his vision limited and any programmes for change run the risk of being discontinued by his successor.

A stringent process for selecting a league commissioner is also crucial for providing consistency in relation to officiating and decision-making. A league commissioner who is wellversed in the Federation of International Basketball Association (FIBA) rules as well that of those of the league rules can ensure intelligent interpretation of the rules, quality officiating and accurate judgments and decisions about controversial calls, protests and controversies Concrete appointment requirements relating to basketball governance experience, leadership, charisma and decision-making ability will also help to professionalize the position of in terms of personal merit and competence.

The appointment of a long-term commissioner can be matched and reinforced by increased empowerment of the position itself. There have been instances in the UAAP's history when the league commissioner's decisions have been overruled, overturned and vetoed by the 
UAAP Board, making the UAAP Board more powerful and more authoritative than the league commissioner. Terrado (spin.ph, 2014) captures the urgency and necessity of empowering the league commissioner over the UAAP Board when he comments:

Finally, the UAAP wants to do away with the controversial practice of game-related issues reaching the board room. A source told Spin.ph there's a strong sentiment among school heads to leave all game-related decisions to the commissioner, stripping teams of the option to appeal adverse rulings before the UAAP board. Insiders said the new rule could be in place by 2015 for Season 78 . The rule change, in effect, will give the commissioner more independence and teeth in running the affairs of the tournament and hand out penalties to players, coaches, and team officials in game-related issues. Currently, the decision of the commissioner is not considered final since it can still be appealed before the board, which in turn can either upheld or reverse the verdict.

In effect, a deliberative, consensual, participatory and stakeholder approach to selecting the league commissioner is important as a viable alternative to the practice of a league commissioner appointed solely by the host school. Putting recruitment in the hands of university presidents, policy boards, boards of directors, and management committees of all member schools can broaden and even democratize the selection of league commissioners. It could even expand the decision-making structure by allotting seats for student councils, faculty councils, alumni associations and media enterprises to ensure that the choice of league commissioners is democratic and reflective of the entire league community. 


\section{Designation of presidents and rectors as Board of Trustee Members and the formation of risk and audit committees}

The UAAP has recently launch a reorganization intended to make presidents and rectors of member schools automatically become members of the Board of Trustees with current members comprising the Board of Managing Directors, which will manage and supervise UAAP events, including games. To be created under the proposed change are "risk and audit committees, which will be under the Board of Trustees." Meanwhile, other working committees similar to existing committees will be created and placed under the supervision of the board of managing directors. This policy-shift on the part of the UAAP follows a pattern established by the NCAA in which presidents and rectors automatically become member of the board of trustees.

This restructuring would allow the presidents and rectors to be hands-on participants in the planning, formulation and implementation of the plans, programmes and projects of their basketball league and would also reinforce the concept of stake-holding in relation to decisionmaking and ensure a sense of ownership with regards to accountability since presidents and rectors or chief executives of member schools are the ones who become directly engaged unlike in the past when responsibilities were delegated to the board of directors or policy board. Under the rules, each member schools are entitled to two board members, one of whom is either a sports or athletic director and the other a professor or member of the administrations.

This organizational change seeks to ensure an accountability mechanism and reporting requirements of the board of directors or policy board to the University which it represents, specifically to its presidents and rectors, who would now assume a more enhanced role in the league to allay fears of abuse and allegations of manipulation of the board which prior to this 
policy-reform have wielded full discretionary powers to make decision on game-related issues, even circumventing judgments rendered by the league commissioners.

Incidentally, the creation of a risk committee and an audit team which would oversee the conduct of the operations of the league was triggered by allegations of anomalies and misconduct by some board members in the performance of their functions which were attributable to the lack of an accountability mechanism and reporting requirements between the board of directors and university presidents and rectors. Henson (2013) outlines the reasons that led to the creation of a risk committee and audit committee as part and parcel of the organizational structure;

The audit was reportedly triggered by the disenchantment of several school presidents on the way the UAAP Board has been managed through the years arbitrarily and without reporting responsibility or accountability by a group of trustees. A source confided that a provision in the By-Laws grants absolute authority for the trustees to decide on issues without intervention or veto power from school presidents. Apparently, accusations of high-handedness reached the ears of school presidents who are finally putting their foot down to stop the machinations and manipulations of the Board. Cases of horse-trading, gerrymandering and even lack of ethics have been talked about.

The creation of a risk committee and an audit team allows for monitoring specific actions to prevent deviation from and non-conformity with the acceptable and ethical rules and standards set out in the articles of incorporation and the by-laws and constitution of the league. Since it is an independent body tasked to oversee, monitor, check and evaluate the league's rules, policies and procedures under the office of the board of trustees (presidents and rectors), the risk committee can act as a strong overseer without any self-interest in satisfying the reporting 
requirements for the board of trustees. The risk committee and the audit team can also be instrumental in offering possible opportunities for improvement and recommending potential managerial, political and technical capacities which are designed to fill the gaps in the management and operation of the league.

Another organizational reform which the UAAP has made involves the appointment of an executive director. Along with the heads of the member universities, now acting as the trustees, for the first time in 80 years, the Association will have an executive director to oversee its operations. The executive director is charged to managing a variety of assignments. These include implementing policies, providing support to the Board of Trustees, the Board of Managing Directors, and the UAAP Committees, supervising operations, and undertaking special projects (abs-cbn.com 2017).

\section{Ensure the implementation of Republic Act No. 10676 (Otherwise Known as an Act Protecting the Amateur Nature of Student-Athletes in the Philippines by Regulating the Residency Requirement and Prohibiting the Commercialization of Student Athletes)}

President Benigno Aquino III signed Republic Act 10676 or the Student-Athletes Protection Act on 26 August, 2015 during the second regular session of the sixteenth Congress of the Philippines. This act is a consolidation of Senate Bill Number 2226 and House Bill No.5115 which was finally passed and enacted by the Senate and House of Representatives on June 10, 2015 (Official Gazette, 2015).

The new law abolishes the two-year residency rule of the University Athletic Association of the Philippines applied to high school student-athletes transferring to another school or college. Under the new law, student athletic associations shall not impose residency 
requirements on a student-athlete who is a high school graduate enrolling in a college or university. There shall also be no residency requirement imposed on high school student-athletes transferring from one high school to another. However, to address the issue of piracy, a maximum of one-year residency may be imposed by an athletic association on high school student-athletes transferring from one member school to another. For tertiary student-athletes, a maximum of one-year residency may be imposed by an athletic association before a studentathlete can participate and represent a school in any athletic competition (Bacani 2015).

This law is designed to free the student athlete from having his basketball development temporarily arrested. It lowers the residency requirement to one year with regard to the transfer of student athletes from one member school to another. The one-year residency requirement is sufficient for the high school or rookie recruit to adapt to the school system, blend in with teammates and familiarise himself with how to balance academic studies with playing duties as a student.

Section 5 of Republic Act 10676 states that schools may only grant a deserving studentathlete the following benefits and incentives: a) tuition and miscellaneous school fees, including books and learning materials, b) full board and lodging, c) school and athletic uniforms, d) regular monthly allowance, e) medical services, and f) other reasonable and similar benefits that would enhance the academic and athletic performance of student-athletes. Section 6 of the Republic Act 10676 further states that "schools shall not offer a student-athlete or the immediate family member's benefits or incentives beyond those enumerated under Section 5 of this Act which are contrary to the nature of amateur sports and which may result in the commercialization of a student-athlete." 
This section addresses the issue of the commercialization of college basketball by offering a precise enumeration and definition of what benefits and incentives are allowed by law for student athletes and putting restrictions and limitations on benefits and incentives which student athletes can receive. It also explicitly emphasise that schools must instill the amateur spirit in its athletes by not offering the student athlete or his immediate family members benefits and incentives beyond what the law allows. This is aimed at preventing wealthy alumni or businessmen from providing lavish benefits and incentives to players including hefty sums of money, luxury condominiums or apartments, brand new cars or even providing jobs for the player's family members and relatives as lucrative attraction in the recruitment and hiring of top high school players or stars from other leagues.

This law applies to all athletic associations which refers to any public or private organizations responsible for governing inter-school athletic programmes and competitions including, but not limited to, the Private Schools Athletic Association (PRISAA), the University Athletic Association of the Philippines (UAAP), the National College Athletic Association of the Philippines (NCAA), the Women's National Collegiate Athletic Association (WNCAA), the State Colleges and Universities Athletic Association (SCUAA), the Cebu Schools Athletic Foundation, Inc. (CESAFI), the National Capital Regional Athletic Association (NCRAA), the Association of Local Colleges and Universities Athletic Association (ALCUAA) and the National Athletic Association of Schools, Colleges and Universities (NAASCU) (Section 3, Republic Act No. 10676). 


\section{Eligibility extension of players for more than seven years and beyond five playing seasons}

This proposed policy would benefit college varsity teams which recruited top players and college stars from other leagues. It would mean longer playing seasons for talented and skillful players which in turn could create bigger problems with other members schools whose basketball programmes are not as comprehensive and robust as those of elite schools such as the De La Salle Green Archers and Ateneo De Manila University Blue Eagles.

A UAAP rule change can extend the eligibility of players such as Ben Mbala of La Salle and C. J. Perez of Ateneo. The league's board of trustees, sources told Spin.ph, is expected to adjust the players' eligibility timeframe. Currently, the UAAP allows a player seven years in which to play for five seasons. The seven-year period starts when the player graduates from high school. The age limit of 25 among players is also under review.

Transferees and foreign players are expected to benefit from the new rule, implemented at the beginning Season 79, and among them could be Mbala and Perez. The two were recruited by UAAP schools when they were already in college, and under the previous rule, both players had only one season to play in the league. The rule change would make them eligible for Season 80, and possibly beyond. However, sources made it clear that the rule was changed out of necessity as only a few players would be available for college teams in the next years due to the implementation of the K-12 programme (Terrado 2016).

This policy needs careful review and analysis before its full-blown implementation. The UAAP Policy Board must carefully weigh up whether the adoption of such a policy would actually promote and protect the best interests of the league or only of a few members. Prolonging the playing seasons of players in the current roster would essentially deprive other equally talented players in Team B to finally catch sight of college basketball stardom. This 
basically defeats the intent and purpose of the policy as well as circumventing the spirit of removing the two-year residency rule.

However, the advent of the policy extending player's seasons beyond seven years and the consideration of the possibility of extending the player's age limit to more than twenty-five years old are transforming the college basketball league into a playground where fathers play and not their sons. Collegiate basketball should be a playground for promising, youthful and hopeful players not for over-aged and over-staying players who are still allowed to play although they are well past of the eligibility year as a result of a new policy from which only a few schools will benefit because these players who will be allowed to extend their eligibility years are the marquee players and top recruits to those very universities which are lobbying for such policy to be approved by policy boards.

\section{Recruitment and hiring of foreign players by member schools}

In 2012, the NCAA policy board approved the proposal to forbid member schools from recruiting foreign players to their teams, the new rule taking effect from the beginning of 2013. The UAAP allows foreigners to join its member teams and has not yet entertained the idea of bringing this to anend. Under the rule, foreign players must be enrolled in an NCAA school by 2013 to be eligible, with the school having the option to field its recruit after two years of residency (Sacamos, 2013).

There are two sides to this debate, one which considers that the recruitment of foreign imports is good for the league and the other that is diametrically opposed. Those who support the practice argue that allowing foreign players to play in the leagues is good for basketball, 
particularly for local players who like to play competitive basketball. Playing with big, tall imported players challenges them to be more creative and competitive which is invaluable when they begin to face taller and heftier opponents in regional and international competition such as in the ASEAN, the Asia and the World University Games.

This also prepares them for tougher battles ahead in their basketball careers for foreign imports may be good enough to be recruited as professional players in the PBA. Furthermore, hiring foreign imports is consistent with the globalization of the sport which thrives according to the principle of "open basketball" and "borderless basketball" where there is free movement of players from one country to another and as basketball increasingly transcends spatial boundaries. Opposing the inclusion of foreign players therefore runs contrary to the global brand of basketball that FIBA espouses.

On the other side of the debate are those who are against the idea of allowing foreign player to play in collegiate basketball based on two major factors, namely, that foreign players 1) takes the places of a local player in varsity teams and, 2) greatly affect the parity and equity in the league in terms of competitiveness and balanced line-ups.

The first factor implies that Philippine college basketball must give priority and opportunity to local and homegrown players to showcase their basketball skills. Foreign players consequently deprive local college basketball players from getting scholarships, decrease their chances of playing in a college team or diminish the playing time of players already in a team. A problematic aspect this debate is how the presence of imports is immediately seen as a threat and never as an opportunity. Perhaps this has to do with an unfortunate Filipino characteristic of underestimating local abilities or a colonial mentality that sees anything foreign as inherently better. Yet a foreign centre will not automatically be a better player than a Filipino centre. Nor 
should that an import's presence instantly threaten a local player's place on the team. Albeit controlling for size and experience, it is hard work that makes the difference between the two athletes and not their nationality (Kuku 2013).

The second factor involves the parity and balance of competition in the league. Schools which include one or more imports in their line-ups are stronger and more than those that do not employ the services of a foreign import. Although there is a policy that only one import at a time is allowed to be on court, college teams with foreign imports have a comparative advantage over those which do not have foreign imports primarily because foreign imports tend to be heavier and taller that their local counterparts. This can have an important influence on court in terms of rebounds and scoring.

The UAAP could face this problem head on by investigating the recruitment of the existing and incomimg foreign athletes, checking the lifestyles of all the imports and deciding if a school or its supporters was giving these athletes more than is allowed by the league's own bylaws. They could also do the same for blue-chip recruits. They could hire people to do the lifestyle checks. They could also trace the money trail and get amateurism back to where it should to be (Evangelista 2014).

\section{Creating a basketball channel for collegiate basketball in the Philippines and maintain a website for all collegiate leagues}

Finally, to achieve parity in terms of media coverage of the games, television and cable television network executives should mull over the possibility of launching a basketball channel which features various games from different collegiate leagues either on mainstream or cable television. The UAAP and the NCAA are considered to be the most popular college basketball 
league in the Philippines owing to media coverage and the television broadcasting that ABSCBN Corporation - the largest network in the Philippines - has afforded both leagues. While other leagues are also televised by other local television stations, such stations do not parallel ABS-CBN's far wider reach throughout the archipelago in terms of broadband, signal, frequency and speed. Periodically, concerns arise that a particular sport or programme may be "overexposed," resulting in declining viewership. However, this has not been the case with college football and basketball. Television companies and the cable and satellite systems that carry the games learned a long time ago that a game of football or basketball is the best reality show around (Weaver 2013, 16).

But the TV executives cannot be blamed for devoting their broadcasting rights to what are acknowledged as the premier college basketball leagues in the country and where the money is right because UAAP and NCAA basketball games can attract large crowds and a bigger audience share compared with other tournaments which are staged in bigger venues, such as Araneta Coliseum in Cubao, Quezon City and Mall of Asia Arena in Pasay City, which could easily be filled up by more than fifteen thousand fans and supporters every time Ateneo and La Salle plays in the UAAP or San Beda-Letran compete. However, exploring the possibility of broadcasting other equally interesting leagues and games could further generate basketball fans' interest and make college basketball more inclusive in terms of media coverage. It is not only in television broadcasting rights where there is perceived disparity but also in newspaper coverage with the results of games in the UAAP and NCAA making the headlines in the sports sections while other leagues are given less space or not reported at all.

One way of improving the governance of the UAAP, NCAA and other leagues is for each league to maintain a collegiate tournament website to propagate awareness of its league in terms 
of its mission and vision, member schools' profiles, leadership, policies and format, schedule of games, and advocacy programmes. This is one technological innovation by which college basketball leagues, especially the less well known, can reach wider mass appeal. There is also a need to maintain and update these tournament websites because some of them are already out of date. The aim would be to spark even greater interest among college basketball enthusiasts who wish to know more about the leagues, their favourite teams and players, and the schedule of games.

\section{Conclusion}

Collegiate basketball leagues in the Philippine are popular in the Philippines, second only to the professional league - the Philippine Basketball Association. These college basketball leagues have systems of governance which consist of their mission and vision, membership and eligibility rules, structures, processes and future directions and capacities. A system of good governance is in operation within an organization that has been effective in making real progress towards the organization's various objectives and overall vision and is providing a valuable service to its membership (Hassan and Hamil 2012). This article has attempted to explain and analyse the various the aforementioned elements and components of governance that exist in collegiate basketball leagues and tournaments in the Philippines.

Like any organization's system of governance, college basketball organizations are not exempt from encountering governance issues and challenges which can engulf them. Some of these emerging issues and challenges include much too powerful boards of directors, lack of accountability mechanisms, commercialization and corporatization of college basketball leagues, 
recruitment of foreign players and coaches, parity in media coverage and the two-year residency rule.

In response to the persistence of these issues and challenges, the article has also sought to consider policy-capacity approaches which college basketball leagues have adopted or may adopt to address problems. These approaches include 1) Deliberative Appointment and Empowerment of a Long-Term Commissioner, 2) Designation of Presidents and Rectors as Board of Trustees and Creation of Risk and Audit Committees 3) Ensuring the Promulgation and Implementation of Republic Act No. 10676 Otherwise Known as an Act Protecting the Amateur Nature of Student-Athletes in the Philippines by Regulating the Residency Requirement and Prohibiting The Commercialization of Student Athletes, 4) Extending the Eligibility of Players for More than Seven Years and Beyond Five Playing Seasons, 5) Recruiting and Hiring of Foreign Players by Member Schools, and 6) the Creation of a Basketball Channel or Station for Collegiate Basketball in the Philippines and Maintain A Website for All Collegiate Leagues.

Whatever policy-capacities may be present or absent, college basketball leagues must continue to investigate and search for whatever best possible solutions are available based on good governance which ensures that all of their actors and stakeholders' active involvement, deliberative engagement sand participatory discourses are taken into consideration in the collective pursuit of the best outcomes for the leagues and their member schools. As concepts of systematic and political governance imply, the use of the term 'governance' in place of 'government', reflects a recognition that, in contemporary developed economies, governing decisions can no longer be taken by governments alone (whether national or local). Rather effective decision-making in public policy needs to incorporate other stakeholders from the 
commercial and/or voluntary sectors thereby reflecting the interconnectedness of change (Henry 2009).

Finally, the article argues that college basketball leagues and their actors and stakeholders must develop craft policies which generally seek to promote and protect of the leagues' interests, its member schools and most of all its basketball fans, on the basis of democratic governance and the true spirit of amateurism which is central to college basketball. Writing about upholding the cultural significance and values of college basketball through democratic principles and the spirit of amateurism, Price $(1991,57)$ concludes:

Finally, we also sanction our fascination for the tournament with a democratic model of establishing initial equality, that the oppressed or neglected team might make it all the way to the top. The initial equality of teams is marked by their amateur character and the single elimination format of the tournament. No professional player can rescue or sink a team; and every team faces the equal threat of elimination after a single defeat. Because of its amateur status, the tournament and its championship are not threatened by personal greed of players seeking salary renegotiation or by the collective action of the players striking for increased benefits.

In the end, for college basketball to continue grow and prosper in the Philippines, its actors and stakeholders must always uphold the basic tenets of democracy, equality and amateurism with the presidents of member schools taking an increasingly leading role in democratic basketball governance and with league commissioners enjoying a more powerful and longer period in office. Deliberative, participative and consensual and approaches must prevail. It is love of the game and loyalty to their alma mater that motivates the players to work hard and compete for prizes. 


\section{References}

Abs-cbn sport. Com. 2017. UAAP appoints new executive director. Retrieved from http://sports.abs-cbn.com/uaap/news/2017/08/09/uaap-appoints-new-executive-director$\underline{29523}$

Antolihao, Lou. 2015. Playing with the Big Boys: Basketball, American Imperialism, and Subaltern Discourse in the Philippines. Lincoln and London: University of Nebraska Press.

Bartholomew, Rafe. 2011. Pacific Rims: Beermen Ballin' in Flip-Flops and the Philippines Unlikely Love Affair with Basketball. New York, New York: New American Library Penguin Books.

Bacani, Louis. 2015. “New Law Scraps UAAP's Two-year Residency Rule Bans Huge Bonuses." Retrieved from http://www.philstar.com/sports/2015/08/28/1493307/new-law-scraps-uaaps2-year-residency-rule-bans-huge-bonuses.

Chan-robles .com. NCAA structure - Philippines sports page. Retrieved from http://www.chanrobles.com/ncaabasketballstructure.html\#.WYvdY9LyvIU

Dy, Charlene. 2005. "How Far College Teams Bend The Rules." Retrieved from http://pcij.org/stories/how-far-can-college-teams-bend-the-rules/

.Evangelista, Cholo. 2014. “Banning Foreign Players Cowards Way.” Retrieved from http://www.slamonlineph.com/banning-foreign-players-cowards-way/

Groeneveld, Margaret and Houlihan, Barrie. 2012. Social Capital and Sport Governance in Europe (Routledge Research in Sport, Culture and Society). New York and London: Rouledge Press, Taylor and Francis.

Hassan, David \& Hamil, Sean. 2012. Who Owns Football: Models of Football Governance and Management in International Sport. New York: Routledge Press.

Henry, Ian. 2009. Transnational and Comparative Research in Sport: Globalization, Governance and Sport Policy. London and New York: Routledge Press, Taylor and Francis. 
Henson, Joaquin M. 2013. New order in UAAP. Sporting Chance, The Philippine Star. Retrieved from http://www.philstar.com/sports/2013/12/26/1272139/new-order-uaap

Hoye, Russel \& Cuskelly, Graham. 2007. Sports Governance. London and New York: Routledge Press.

Juico, Vincent. 2014 November 7. Commercialization of College Sports. in Sports without borders. Retrieved from http://www.businessmirror.com.ph/commercialization-of-collegesports/

Kuku, Itunu. 2013. A Foreigner's Thoughts on Import in the UAAP. Retrieved from http://www.gmanetwork.com/news/story/317501/sports/a-foreigner-s-thoughts-on-importsin-the-uaap

Lichauco, Joseton and Jacinto, Luigi. 2014. 10 Questions for a UAAP board member. Retrieved from http://thelasallian.com/2014/12/22/10-questions-for-a-uaap-board-member/

Liao, Henry. 2014. Foreign Student Players. Retrieved from http://bandera.inquirer.net/68151/foreign-student-players\#ixzz48RcS9nNm

Mitten, Matthew J. and Davis, Timothy. 2012. Sports Law: Governance and Regulation. Frederick, MD/New York, New York: Kluwer Law and Business in New York.

O'Boyle, Ian \& Bradbury, Trish. 2013. Sport Governance: International Case Studies (Foundations of Sport Management). New York, NY: Routledge Press, Taylor and Francis.

Officialgazette.gov.ph. Republic Act No. 10676. Retrieved from http://www.officialgazette.gov.ph/2015/08/26/republic-act-no-10676/

Oliphant, Samuel \& Michael Howlett. 2010. "Assessing Policy Analytical Capacity: Comparative Insights From A Study of the Canadian Environmental Policy Advice System". Journal of Comparative Policy Analysis: Research and Practice 12 (4): (August), 439-445.

Pluff, Gary. 2013. The A-Z Basketball Book: What Every Player Needs to Know to be Great at the Game! Baldwinsville, New York: Upcentral Publishing.

Price, Joseph L. 1991. "The Final Four as Final Judgment: The Cultural Significance of the NCAA basketball championship". Journal of Popular Culture 24 (4): 49-58.

Republic Act Number 10676 Otherwise known as an Act Protecting the Amateur Nature of Student-Athletes in the Philippines by Regulating the Residency Requirement and Prohibiting the Commercialization of Student Athletes. Retrieved from http://www.gov.ph/2015/08/26/republic-act-no-10676/. 
Roque, P. Jude. 2016. Choosing the next NCAA/UAAP Commissioner. Manila Times, Retrieved from http://www.manilatimes.net/choosing-the-next-ncaauaap-commissioner/253821/

Sacamos, Karlo. 2013. Foreign Players a Vanishing Breed. Retrieved from http://www.spin.ph/sports/basketball/special-reports/foreign-players-a-vanishing-breed-inncaa-as-new-rule-set-to-take-effect-v02.

Terrado, Reuben. 2016. UAAP Rule Change Extend Eligibility. Retrieved from http://www.spin.ph/basketball/uaap/news/uaap-rule-change-extend-eligibility-transfereesimports-la-salle-ben-mbala-ateneo-cj-perez.

Terrado, Reuben. 2014. Finally, UAAP board members want commissioner's decision to be final in game-relate issues. Retrieved from http://www.spin.ph/sports/basketball/news/fnally-uaap-board-members-wantcommissioners-decision-to-be-final-in-game-related-issues

Weaver, Karen. 2013. "Media Deals, College Football, and Governance: Who's in Charge?" Change 45 (4): 15-23. DOI: 10.1080/00091383.2013.806181.

Whittemore, R., \& Knafl, K. (2005). “The Integrative Review: Updated Methodology.” Journal of Advanced Nursing 52: 546-553.

Wikipilipinas.org $\quad$ NCAA $\quad$ Philippines. $\quad$ Retrieved from http://en.wikipilipinas.org/index.php/NCAA_(Philippines) 
